Journal of the Society for the Study of Architecture in Canada Le Journal de la Société pour l'étude de l'architecture au Canada

\title{
A Concrete Artistic Vision
}

\section{John Leroux}

Volume 45, numéro 1, 2020

URI : https://id.erudit.org/iderudit/1075072ar

DOI : https://doi.org/10.7202/1075072ar

Aller au sommaire du numéro

Éditeur(s)

SSAC-SEAC

ISSN

2563-8696 (numérique)

Découvrir la revue

Citer cet article

Leroux, J. (2020). A Concrete Artistic Vision. Journal of the Society for the Study of Architecture in Canada / Le Journal de la Société pour l'étude de l'architecture au Canada, 45(1), 2-9. https://doi.org/10.7202/1075072ar d'utilisation que vous pouvez consulter en ligne. 


\section{A CONCRETE ARTISTIC VISION}

JOHN LEROUX has practised in the fields of art

history, architecture, visual art, curating, and education, and he is currently the manager of collections and exhibitions at the Beaverbrook Art Gallery. He holds a bachelor of architecture from McGill University, a master's in art history from Concordia University, a Ph.D. in history from the University of New Brunswick, and he was a team member of Canada's entry at the 2012 Venice Biennale in architecture. He has taught at the University of New Brunswick, St. Thomas University, and the New Brunswick College of Craft and Design. John has authored thirteen books, including Building New Brunswick: An Architectural History and The Lost City: Ian MacEachern's Photographs of Saint John.

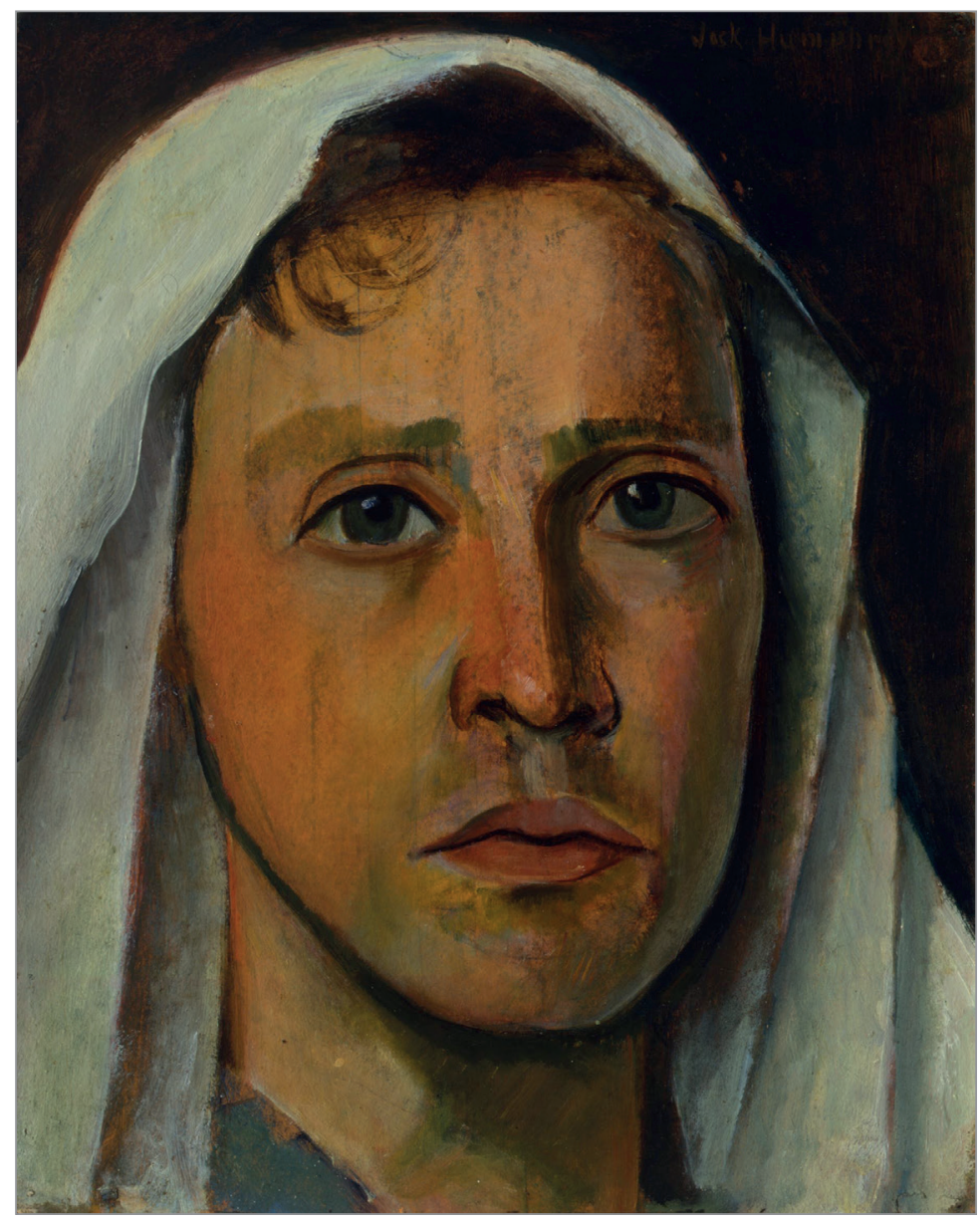

FIG. 1. JACK HUMPHREY, DRAPED HEAD, 1931, OIL ON PANEL, 42.5 X 34.5 CM, GIFT OF THE GRADUATING YEAR, 1937. | HART HOUSE COLLECTION HH1937.002. COURTESY OF THE ART MUSEUM AT THE UNIVERSITY OF TORONTO.

\section{$>$ JOHN LEROUX}


that the European avant-garde venerated the new industrial infrastructure that the Maritime dockworkers laboured alongside. Hints were shared, however, by local artists who held intimate knowledge and respect for the workings and forms of the port architecture, along with a modern artistic vision that spoke to the zeitgeist.

In the 1930s and 1940s, a group of Saint John artists, including Miller Brittain [1912-1968], Jack Humphrey [1901-1967], and others, gave Saint John the reputation of a city "which, size for size, probably contained more serious artists than any other in Canada."1 Brittain and Humphrey were schooled under modern American artistic influences in New York before their return to Saint John in the 1930s, forced back during the Great Depression for economic reasons. Humphrey had studied for five years at the National Academy of Design, while Brittain attended the Art Students League. Born and raised in Saint John, Brittain and Humphrey rose to national prominence and attention through articles, exhibitions, and publications that lauded their staunch commitment to a gritty realism that stemmed directly from observing their immediate civic surroundings. This vision often depicted the daily lives and built environments of blue-collar workers and those on the margins of society, all through a modern lens.

The early- to mid-twentieth century urban surroundings of Saint John were the genius loci where New Brunswick's social, economic, and cultural relations formed at brisk speed compared to generations before. Interwar-era Saint John saw itself as a modern city, but it was multifaceted and economically stratified. The social conditions of the shabby working-class housing only a short walk from the port were rarely presented publicly as compared to the city's industrial prowess, and it would be up to artists to visually fuse these two worlds into a modern aesthetic.

As Canada reached its half-century mark, the nature of what constituted meaningful "national" visual art was complex and partially obscured, often in the hands of rigid academies or parochial bureaucrats who controlled the National Gallery of Canada. ${ }^{2}$ In contrast to Canadians who subscribed to the notion of a universal canon of national art that best represented Canada (that is, the Group of Seven), ${ }^{3}$ New Brunswick's professional artists of the 1930s challenged the authority of landscape, honing their eyes and skills more often than not on the city and its people. ${ }^{4}$ This transformation from a landscape focus concurred with the disbanding of the Group of Seven and its members' inclusion in the larger "Canadian Group of Painters" (formed in 1933). Membership stretched across the country-including Jack Humphrey who was officially welcomed to the Group in 1939..$^{5}$

Descended from an original Loyalist family who settled in Saint John, Miller Brittain had deep roots in the city, and held a more conservative temperament fused to the sensibilities of the area. He once stated that: "A picture ought to emerge from the midst of life and be in no sense divorced from it ... And I think that artists should be rooted in their native heath, not self-consciously but naturally. And they will be so if their life and work are one and the same." 6 Artist Pegi Nicol MacLeod went so far as to equate Brittain's vision with the very essence of modern Saint John. She felt his potential of capturing a tangible sense of place should be imported to the rest of the nation:

The gap is being filled so far as con- younger painters broaden it to include Vancouverness, Ottawaness, Torontoness, etc., as we have Saint Johnness, Canadian art has some future . . . The first Miller Brittain came as a therapeutic shock, setting free the spring of my wish. Man at last. Not archaic man, but present-day man; complicated and modern. Just like all of us. ${ }^{7}$

The work of Brittain and Humphrey during the 1930s and 1940s is representative of a new subjectivity within Canadian art which emerged during those decades: the need to reflect the faces, workplaces, and lives of all levels of Canadians, and particularly those in urban centres. Saint John was fertile ground in which to foster a contemporary artistic environment, where a modern vision revealed the Canadian citizen, both rich and poor, as its subject (fig. 1). The foil was often the city, and in its depiction could be found either the pessimism of urban squalor and poverty, or the promise of civic monumentality and vitality. To that effect, two relatively unknown newspaper drawings by Brittain from the mid-1930s present a vibrant and energetic industrial metropolis that is aspirational in its form, making it a distinct connection to the modern development hopes for the region. The images consciously employ a background of industrial architecture and infrastructure to bring this point home.

In the 1930s, the commercial core of Saint John was centred on its port, which continued to be tied to the city's self-image, its potential to draw capital, as well as its international connections. Its artists shared this vision, as the harbour was a busy gateway to the rest of the world. Saint John's harbour was the primary location for observing the vibrant activity of visiting ships, hardworking longshoremen unloading steel steamers, and the landing of new immigrants, all within a stone's throw of some of the wealthiest 


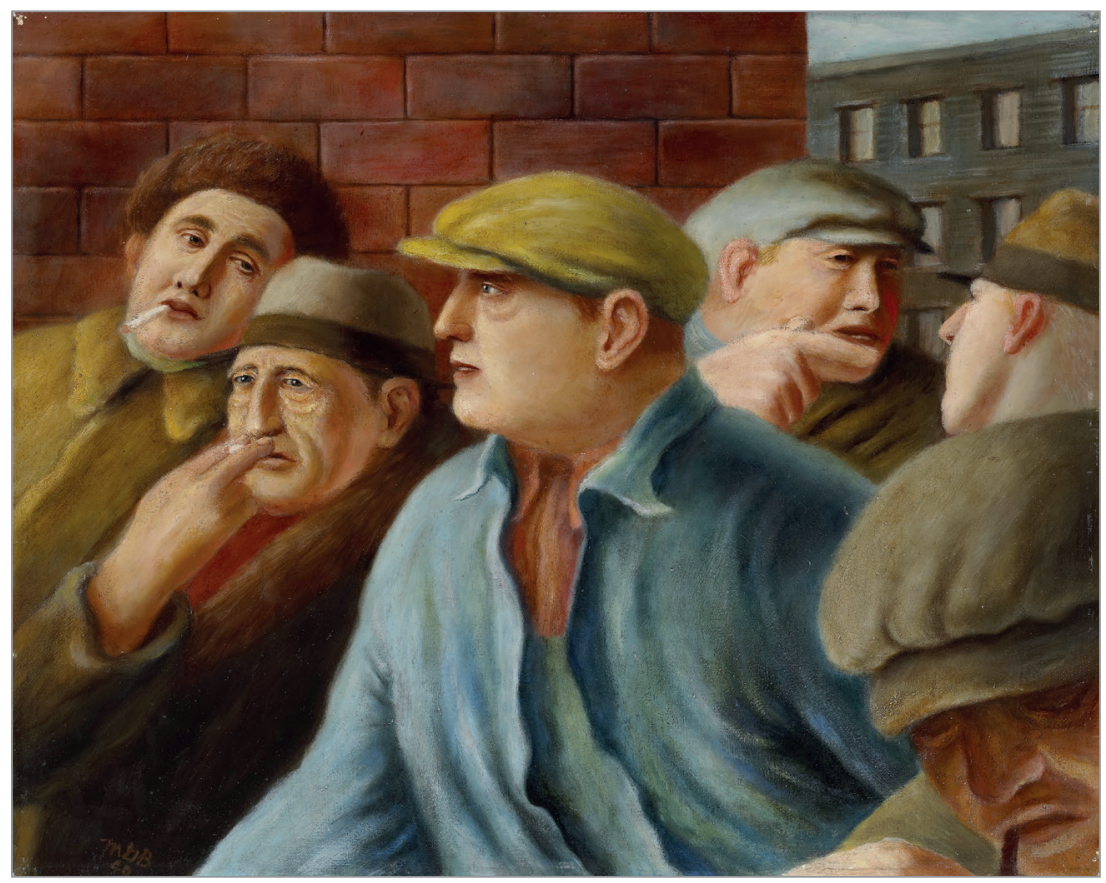

FIG. 2. MILLER BRITTAIN, LONGSHOREMEN, 1940, OIL ON MASONITE, 50.8 X 63.4 CM. | COLlECTION OF THE NATIONAL GALLERY OF CANADA, OTTAWA, PURCHASED IN 1970.

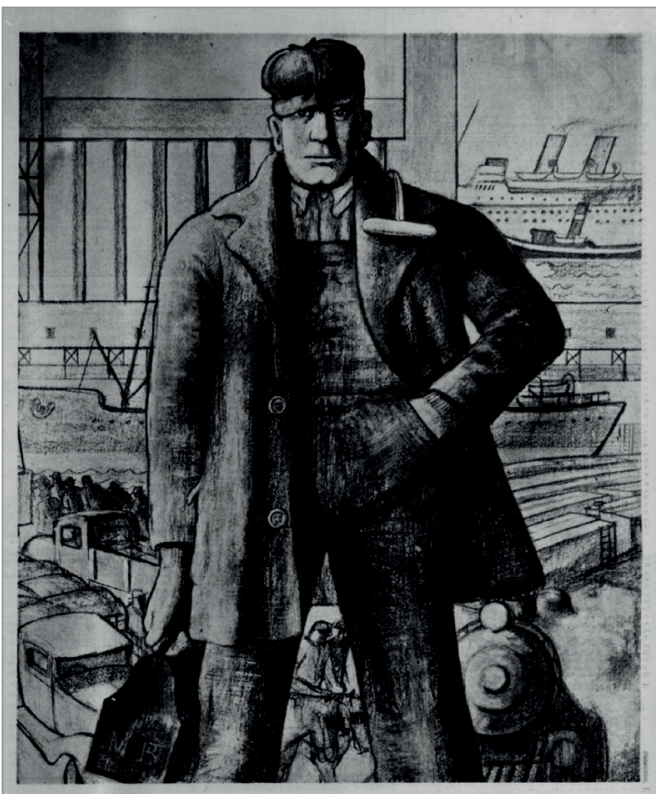

Shipment of Canadian Goods Via Canadian Ports Means More Money for Canadian Workers

FIG. 3. MILLER BRITTAIN, "LONGSHOREMAN," 1936. | TELEGRAPH-JOURNAL [SAINT JOHN], NOVEMBER 30, 1936, P. 7. people in eastern Canada in one direction and nearby slums in the other. With cheap downtown rents and upper-floor studios, the area created an ideal setting for Saint John's artists to establish close studios, forming what was described in 1947 by Canadian Art magazine as a "distinctive

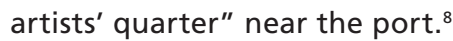

For the city to live and prosper, the leaders of Saint John understood that the municipality had to look seaward and landward, and "keep her fingers on the pulse of trade flowing east and west." Her citizens were encouraged to "think in terms of ships and railroads, of docks and elevators, of all those technical matters." ${ }^{\prime 9}$ By the mid-1930s, public sentiment fuelled by an optimistic hope for better times ahead approvingly considered its rebuilt port and modern facilities:

the port breathes a new romance. It is not the romance of wooden ships and iron men, nor of picturesque shipyards, but the romance of twentieth century trade-of farm and factory and forest and mine, of speed and mass production. In sheds piled high with freight each commodity has its story. There is the story of rubber made into tires, the story of steel, the story of automobiles, of tea, of a gigantic packing industry. There are stories of flour mills and the lumber woods and a thousand and one things - stories of great individuals and great enterprises. ${ }^{10}$

Humphrey and Brittain were consistently drawn to the activity and humanity of the port. Brittain himself once worked as a longshoreman. This influenced his best known work, Longshoremen, now in the collection of the National Gallery of Canada (fig. 2). ${ }^{11}$ While Longshoremen focuses on the energy, character, and implied interpersonal relationships of the blue-collar workers who manned the city's port, a little known drawing of
Brittain's prominently published in the Telegraph-Journal on November 30, 1936, visually expresses the role of the longshoreman as a key and commanding part of the physical modernization that was taking place in New Brunswick (fig. 3). A frontispiece for a multi-page "Shipping Supplement" that boasted of the progress and construction of infrastructure, the artwork made plain the zeitgeist (or hopes therein) of the port and the city of Saint John.

A headline promoting "Saint John, Port of Opportunity, Beckons to Commerce of the Seven Seas," along with bursting warehouse photos captioned by "Trade-life blood of the nation-as it flows through the big steel and concrete sheds of Saint John's modern harbor facilities," used Brittain's singular image to consolidate the intended message. In the foreground of the black and white drafted image, Brittain depicts a muscular and confident 


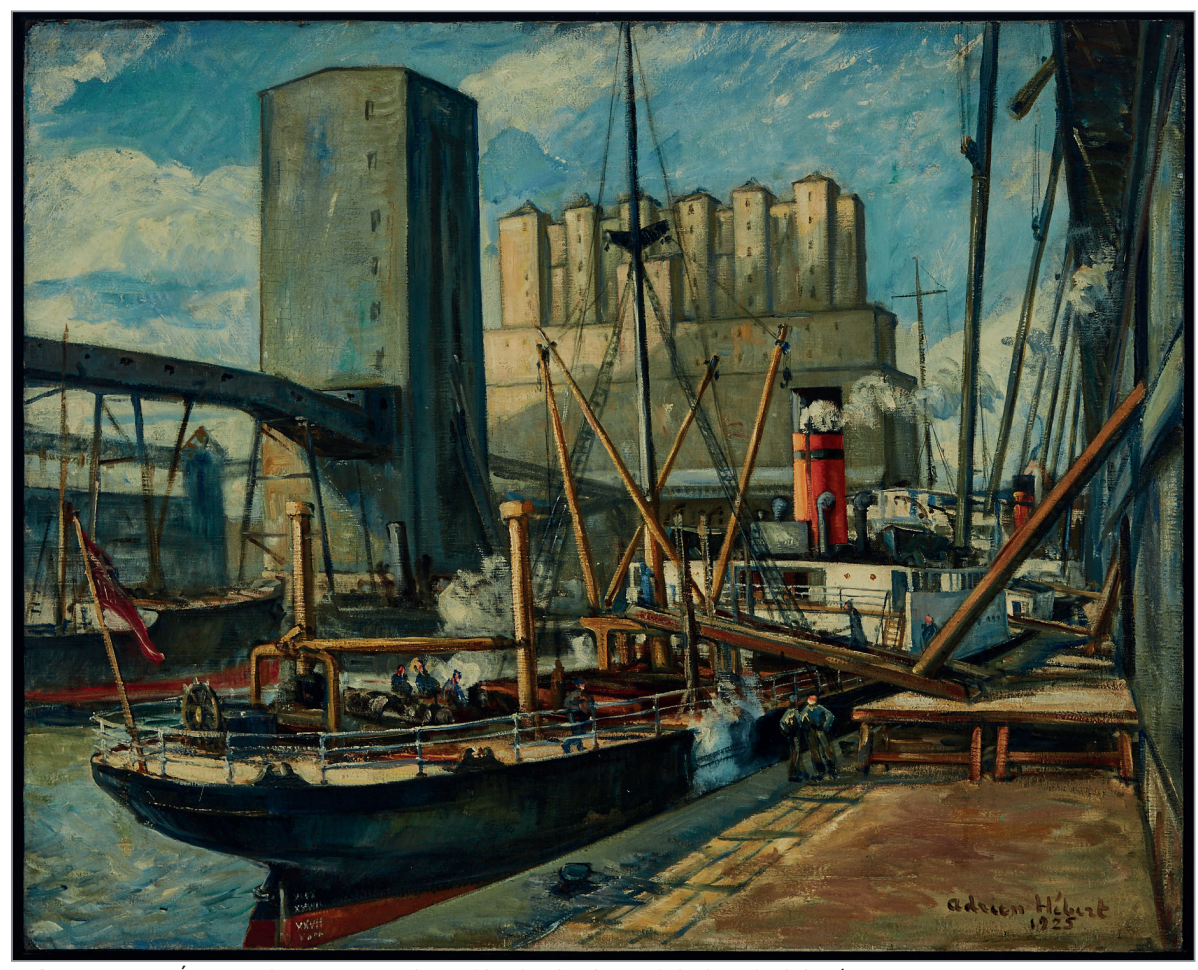

FIG. 4. ADRIEN HÉBERT, MONTREAL HARBOUR, 1925, OIL ON CANVAS, 81.3 X 101.6 CM. | PRIVATE COLLECTION.

male figure clothed in a longshoreman's coat and cap, ready for work with his lunchbox in one hand (subtly monogrammed with a MB) and a longshoreman's hook atop his other shoulder. ${ }^{12}$ Behind the man is a middle ground filled with masses of similarly capped workers, pickup trucks going in all directions, and a billowing steam engine with a throng of boxcars. In the background are a series of ships (a tanker, tugboat, and a huge passenger liner) and a geometric concrete terminal grain elevator with its repetitive cylindrical silos.

Brittain used the grain elevator as a formal compositional device that not only offers a bright minimalist counterpoint to the darker grittiness of the workers and trains, but is also a clear connection to avant-garde European modernists who derived inspiration from the functional of this monumentality; asymmetry of forms; an emphatic direction of movement which increases towards a clearly felt external axis and creates the feeling which is typical of the mechanized city; a composition which is strong and indestructible . . . and, finally, the special richness and acuity of texture of the materials in the alternation of the expressively silhouetted dynamism of iron and steel with the strenuously resisting stability of stone and reinforced concrete, and the glinting of glass which connects it all . .

Such is the role of industrial architecture-the role of a binding link whose principal value for us consists in its everyday sobriety and quotidian reality, the bringing of the creative quest down to the firm soil of the present day, and in the confinement of our above-the-cloud dreaming to the bounds of the possible, realizable and truly necessary. ${ }^{14}$

This grain elevator as a symbol of industrial dynamism and architectural change in Saint John had parallels throughout concurrent art practices in Canada and the United States. Canadian painters Adrien Hébert, Charles Comfort, and Marion Scott used port grain elevators as central imagery in their art (fig. 4), while south of the border, a group of modern artists known as the Precisionists embraced the structures in many of their sharp-edged paintings and photographic works. Some of Charles Sheeler and Charles Demuth's most acclaimed precisionist canvases presented these concrete and steel behemoths, such as Demuth's My Egypt (1927) and Sheeler's Classic Landscape (1931) (fig. 5). Sheeler appreciated and admired their functional, mechanical forms that communicated both modernity and efficiency, connecting them with a spiritual, expansive depth:

Every age manifests itself by some external evidence. In a period such as ours when only 


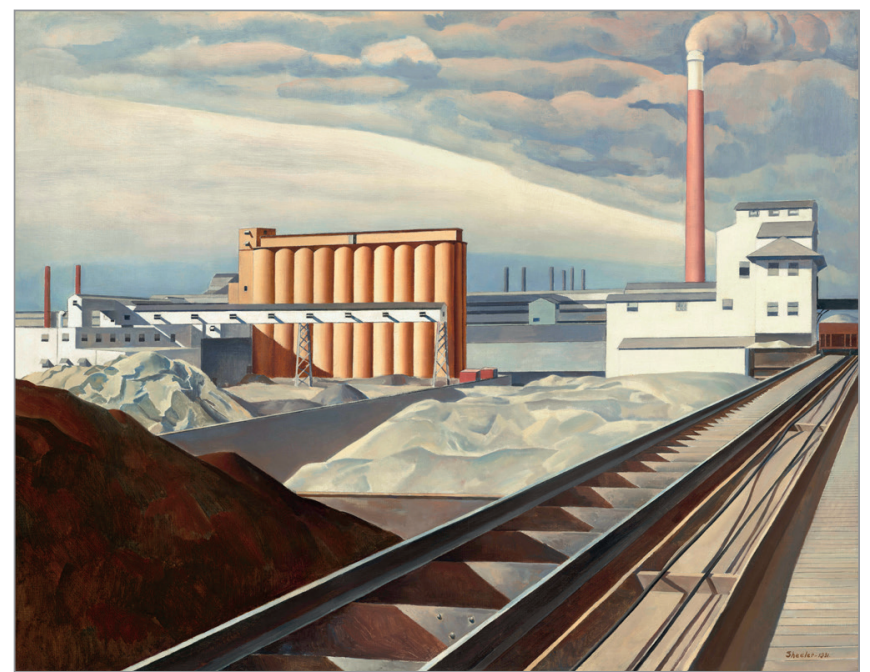

FIG. 5. CHARLES SHEELER, CLASSIC LANDSCAPE, 1931, OIL ON CANVAS, 63.5 X 81.9 CM. | BARNEY A. EBSWORTH COLLECTION, NATIONAL GALLERY OF ART, WASHINGTON, DC.

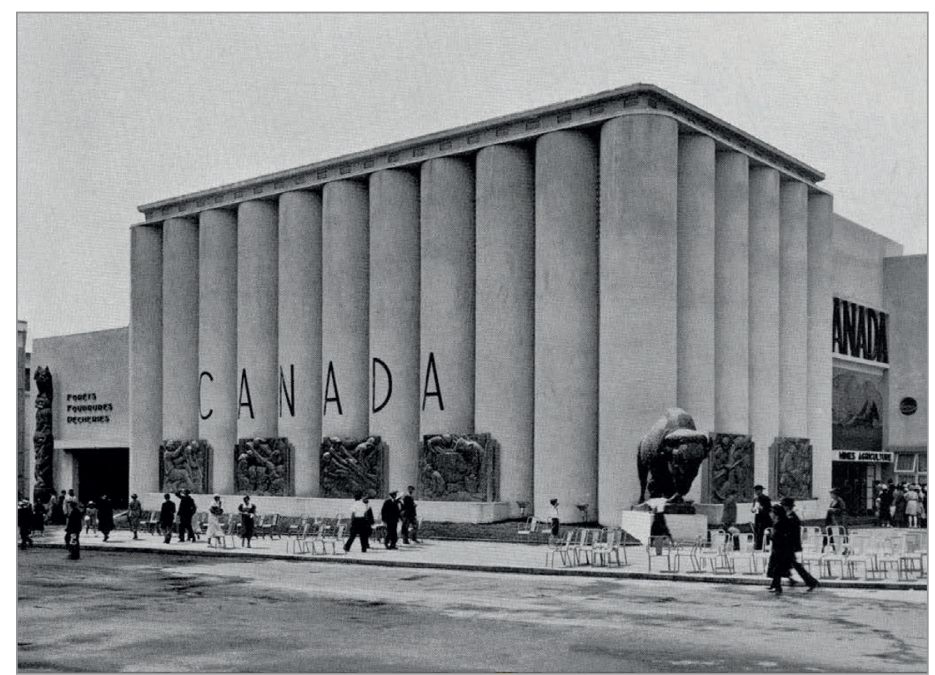

FIG. 6. CANADIAN PAVILION, 1937 WORLD'S FAIR, PARIS, FRANCE. | ÉMILE BRUNET. FROM JOURNAL, ROYAL ARCHITECTURAL INSTITUTE OF CANADA, VOL. 14, NO. 10, OCTOBER 1937, P. 203. a comparatively few individuals seem to be given to religion, some form other than the Gothic cathedral must be found. Industry concerns the greatest numbers - it may be true, as has been said, that our factories are our substitute for religious expression. ${ }^{15}$

Embracing the heroic and emotional aspects of the concrete siloed form, Canada's national pavilion at the 1937 World's Fair in Paris was modelled after a terminal grain elevator with its grouping of concrete silos (fig. 6):

The industrial symbol that evolved in the early twentieth century, and which was specifically identified with Canada, both nationally and internationally, was the terminal grain elevator. It symbolized wheat, the West, and Canada's role as the "breadbasket of the world." For artists, the grain elevator, both as a built form and as a working industrial operation, became a powerful and erudite symbol of "modernism" and the massive scale of industrial architecture. ${ }^{16}$

Through the smoke, the movement, the overtly "workingman" male figures, and modern engineering structures, the message of Brittain's longshoreman drawing was clear: Saint John considered itself as a cog in the gears of a new modern world. To thrive as an industrial and commercial powerhouse, the city needed a public embrace of architectural and transportation infrastructure. In addition to the importance of capital, the individual worker was given full respect as a heroic figure that effectively fuelled the engine of progress. This recalls the period's quixotic notion of the "huge machines of modern construction" and the engineering thrust that "massed their men for the battle against time" during Saint John's 1931 waterfront port rebuild that was necessary to maintain the city's lifeblood: ${ }^{17}$

In the Harbour Commission's drafting rooms . . . engineers pored over plans, gave orders . . . In factories, sweating labourers fabricated steel. The activity was electric . . Concrete wharves took shape, wharves of the most modern type. Surefooted structural steel workers, who walked nimbly and fearlessly over narrow beams at dizzy heights, strung girders. Rivethammers bat a pizzicato. White hot rivets sizzled through the air, tossed from tongs to bucket. And there grew a new skeleton, not the black desolate skeleton left by fire, but the steel framework of a new hope.18

Several months after Brittain's drawing appeared in print, Ontario sculptor Elizabeth Wyn Wood echoed the optimism of the new technical engineering/ art world that connected Canadians to the globe: "Modern communication and the continuing peace of our land have made us at least continental. The pulse beat behind American architecture, Mexican murals, Canadian painting, and all the North American engineering arts is our life force." ${ }^{19}$

Brittain repeated a kindred approach to his port drawing, both compositionally and thematically, six months later when he submitted another artwork to the Telegraph-Journal. His "Loyalist Day" drawing was on the front page of the May 18, 1937, edition. Here, a stately male Loyalist wearing a long coat embraces a 
female figure to his right (fig. 7). The middle ground features tall masted wooden ships and the harbour with hills beyond, while the upper background sports a modern harbourside skyline with industrial buildings, smokestacks, and church spires set tightly together, with a concrete grain elevator matching the 1936 drawing in the middle. The caption adheres to the allegory of the "enlightened" Loyalists of Saint John:

\footnotetext{
They came not as beaten refugees seeking sanctuary but as resolute pioneers determined to overcome rugged wilderness and claim for themselves a home where they could live as they choose-under the British flag . . . In this picture Miller Brittain depicts a Loyalist couple on that May day of long ago looking up from the shore at the rocky hills on which they would build a city, envisioning the future ... Perhaps they were enunciating the words of Ward Chipman uttered when he first entered the harborthe words that became Saint John's motto: "O fortunati quorum jam moaenia [sic] surgunt"- "O fortunate people whose walls are already rising." In the background is the artist's conception of their vision-the skyline of the city which was to be. ${ }^{20}$
}

These tropes of heroic figures bound by the Canadian landscape and a conglomeration of industry had period precedents. Centrepieces that were young, virile, and metaphorically ready to take on the weight of the world laid bare the message that the land and its resources were here for the taking. ${ }^{21} \mathrm{~A}$ notable likeness is the cover for "On the Tide of Prosperity," published in 1927 by the Ontario government to commemorate the fiftieth anniversary of Confederation (fig. 8). Curator Andrew T. Hunter notes that the poster's young figure raising his arms in a " $V$ " for victory is a fitting analogy to the interwar pursuit of resource extraction and the heroism of industry. Myopic in retrospect to environmental and social costs of such sweeping transformation, it was a familiar approach depicting the imminent changes hitting the Western world. ${ }^{22}$

Taking a shot at the national neglect of artists from the Maritimes, columnist Graham Mclnnes labeled Brittain as "one of Canada's forgotten men, from east of Maine." Mclnnes added that the country needed to heed the new art coming out of Saint John as "there are ties, in pictures such as these, more enduring than the steel ribbon over which the Ocean Limited travels, uncaringly, across the provinces which were once Canada's greatest." ${ }^{23}$ It was remarkable to assert that Brittain's drawings had as meaningful a connection to nation-building as the railway, and this demonstrates how eager Canadian critics were for socially conscious modern art and culture to take a leading role.

A convergence of Canadian artists and society occurred at a seminal event, which was attended by both Brittain and Humphrey: the 1941 Kingston Conference of Canadian Artists. ${ }^{24}$ Walter Abell, one of the conference organizers, gave an opening speech entitled "Art and Democracy," where he preached of artists playing a role in the renaissance of democracy. ${ }^{25}$ He urged the assembled to consider the value of widespread "cultural reconstruction," 26 of "architecture, town planning, the decorative arts like textiles and pottery, the industrial arts including everything from vanity cases to motor cars, and public utilities such as highways, dams, and bridges."27

Saint John supported a modern artistic vision during the Great Depression and the Second World War, transcending the city's perceived financial and critical shortcomings. Miller Brittain and Jack Humphrey, whether professionally conflicted or collegially aligned

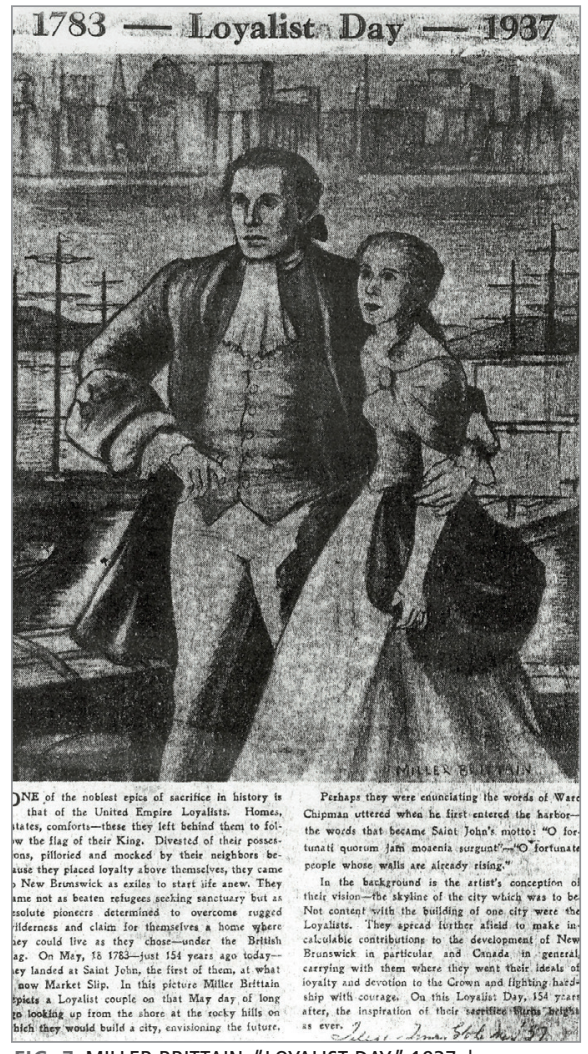

FIG. 7. MILLER BRITTAIN, "LOYALIST DAY," 1937. | TELEGRAPHJOURNAL [SAINT JOHN], MAY 18, 1937, P. 1.

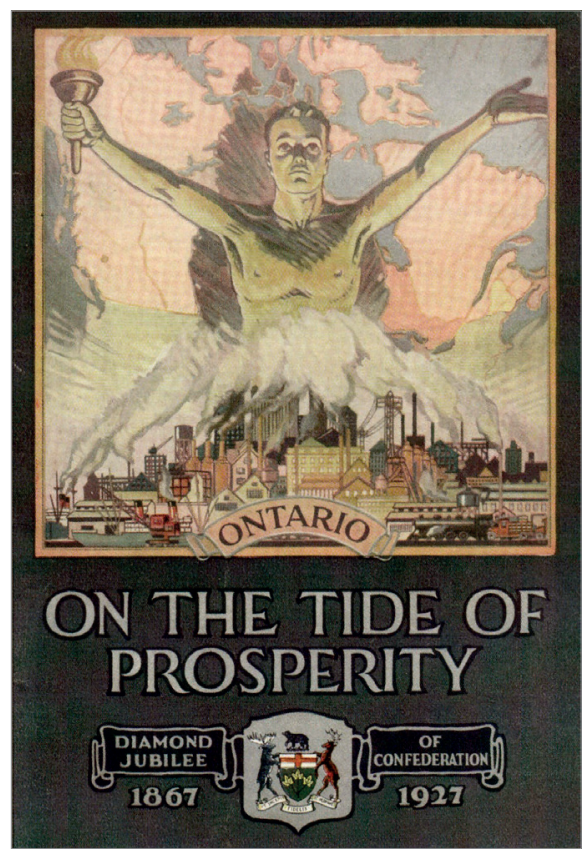

FIG. 8. COVER OF ON THE TIDE OF PROSPERITY, BOOKLET, 1927. | PROVINCE OF ONTARIO. 
depending on the day, were in the midst of a modernist path of artistic development that was analogous with artists in any other "progressive" area of Canada at the time. Kirk Niergarth carefully reflects this in his study of the artists of Saint John in the interwar years:

Brittain and Humphrey were far from isolated from contemporary trends in the years of the Depression and war. They were actively engaged by contemporary debates about aesthetic modernity and the role of art and artists in society. They attempted to synthesize aspects of the art of the past-drawn from a selective tradition: Rembrandt, Cézanne, Blake-with modern developments_-Picasso, Matisse, Riverain pursuit of a new realism, a new renaissance, a social modernism. Humphrey and Brittain were neither ahead of their time nor behind their time: they were of their time. ${ }^{28}$

The Saint John artists' concerns were not simply ones of aesthetic style and social voice. They formally expressed the spirit of modernity in subjects that were local, but also formally and functionally connected to international waves of modern architecture, design, commerce, and philosophy. These connections have not been given due scrutiny, as they have been habitually eclipsed relative to the art's tangible social messages and stylistic modes. The era's socioeconomic and political evolution was immense, and it was clearly expressed in modern forms that dovetailed with the public's expectations of where the region was headed, and how it needed to embody that direction. The immediate pre- and post-war art and architectural aspects of visual culture were burgeoning in $\mathrm{New}$ Brunswick, but the breadth of design in industrial plants, transportation infrastructure, and civil infrastructure are often left out of the modern visual narrative. These not only helped fuel the recovery of New Brunswick sociopolitical life, they reflected the expansions in economic development and public loyalty offered to a region whose journey was leading toward modernity.

\section{NOTES}

1. Mclnnes, Graham, 1948, "Painter of Saint John," Canadian Art, vol. 5, no. 4, p. 170.

2. Dawn, Leslie Allan, 2006, National Visions, National Blindness: Canadian Art and Identities in the 1920s, Vancouver, University of British Columbia Press, p. 6-30.

3. While Lawren Harris and Arthur Lismer painted some notable works in Nova Scotia during the Group of Seven tenure, they, and the other members, never had any episodes of painting in New Brunswick. The only member of the Group to have ever done so was A.Y. Jackson, who painted on the outskirts of the Fredericton region many years after the Group had disbanded.

4. A number of recent scholarly histories of New Brunswick visual art during the early twentieth century have been written, making headway into challenging this centrist national narrative. Key instances include: Niergarth, Kirk, 2015,"The Dignity of Every Human Being": New Brunswick Artists and Canadian Culture between the Great Depression and the Cold War, Toronto, University of Toronto Press; Paikowsky, Sandra, 2006, "'From Away': The Carnegie Corporation, Walter Abell and American Strategies for Art in the Maritimes from the 1920s to the 1940s," Journal of Canadian Art History, vol. XXVII, p. 36-72; and Kelly, Gemey, 2006, "Regionalist or Canadian Modern: Jack Humphrey's Claim to Fame," Journal of Canadian Art History, vol. XXVII, p. 76-91.

5. Boutilier, Alicia (ed.), 2013, A Vital Force: The Canadian Group of Painters, Kingston, ON, The Agnes Etherington Art Centre and the Robert McLaughlin Gallery, p. 133.

6. As quoted in Nicol, Pegi, 1941, "Miller Brittain," Maritime Art, vol. 1, no. 4, p. 17-18.

7. Id., p. 14.

8. 1947, "Coast to Coast in Art: A Distinctive Artists Quarter," Canadian Art, vol. 5, no. 2, p. 85.

9. Sclanders, Ian, 1935, "The Port," in Frederick William Walace (ed.), The Romance of a Great Port: The Story of Saint John New
Brunswick, Saint John, The Committee of the Transportation Festival on the Occasion of the Silver Jubilee of His Majesty King George V, p. 35

10. Sclanders, Ian, "The Port To-Day," in The Romance of a Great Port, id., p. 51.

11. Niergarth, "The Dignity of Every Human Being," op. cit., p. 96-97 and 174.

12. A Saint John Evening-Times Globe column which ran shortly after the drawing appeared, spoke of the identity of the longshoreman and the attempt to track him down. While it turned out that no one in particular had posed for the face, "Mr. Brittain did have a model for the body. He had, it seemed, caught in his drawing a waterfront type common at this port-a fine type of rugged, industrious labor. Miller Brittain has seen enough of the waterfront to be able to typify its characters with his pencil, for he's a West Sider." "The Man on the Street," The Evening-Times Globe, December 1, 1936, p. 13.

13. Le Corbusier, 1931, Towards a New Architecture, London, John Rodker, p. 25-31. Unlike Europe, New Brunswick relegated almost all Modern design to functional industrial structures until mid-century, when Modernism would finally prevail. The prominent grain elevator and storage structures that anchored the Saint John waterfront for generations would have made the European modernists proud, yet they were hardly considered architecture by the local populace and were gradually demolished during the second half of the twentieth century with no public outcry. The CNR Grain Elevator, built at the south end of Water Street in about 1914, handled grain exports through the port, and its bold reinforced concrete form was echoed by several other similar structures around the city's harbour.

14. Ginzburg, Moisei, 1924, Style and Epoch: Issues in Modern Architecture, 2018 reprint, London, Ginzburg Design, p. 133.

15. Charles Sheeler quoted in Rose, Barbara (ed.), 1975, Readings in American Art 1900-1975, New York, Praeger Publishers, p. 81-82.

16. Donegan, Rosemary, 1988, Industrial Images, Hamilton, ON, The Art Gallery of Hamilton, p. viii.

17. Sclanders, "The Port To-Day, op. cit., p. 53.

18. Id., p. 55-57.

19. Wyn Wood, Elizabeth, 1937, "Art and the PreCambrian Shield," Canadian Forum, vol. 16, no. 93 , p. 13-15. 
20. “1783 - Loyalist Day - 1937," TelegraphJournal, May 18, 1937, p. 1.

21. It is worth noting that such figures during this period are almost always white. While the "white savior narrative" trope has racist and colonial undertones, pushing messages of anglo-centric and Euro-centric ethnic morality and superiority, the depth of such depictions are best explored by those who have focused on the subject, including those listed at the online "Whiteness" research entry on the "Oxford Bibliographies" website, [http://www.oxfordbibliographies. com/view/document/obo-9780199791286/ obo-9780199791286-0125.xml], accessed November 12, 2018.

22. Hunter, Andrew T., 2003, The Other Landscape, Edmonton, The Edmonton Gallery, p. 21-22.

23. McInnes, Graham, 1937, "Contemporary Canadian Artists: No. 11-Miller Brittain," Canadian Forum, vol. 17, p. 312.

24. The conference aim was to discuss the place of the artist in society and to investigate the technical concerns of the painter. The meeting also resulted in a resolution to form the Federation of Canadian Artists that would unite all Canadian artists in a common cause, to advance the role of the artist in society, yet still respect regional identity. A broad scope of professional Canadian artists were represented at the Conference: women and men, young and old, and those from the Atlantic, Pacific, and parts in between. Five New Brunswickers took part: Saint John artists and educators Miller Brittain, Jack Humphrey, Julia Crawford, and Ted Campbell, along with Lucy Jarvis of Fredericton.

25. Abell, Walter, "Art and Democracy," in Bell, Michael, 1983, The Kingston Conference Proceedings: A Reprint of the Proceedings of the 1941 Kingston Artists' Conference, Kingston, ON, Agnes Etherington Art Centre, p. 22-33.

26. Id., p. 32.

27. Id., p. 23.

28. Niergarth, "The Dignity of Every Human Being," op. cit., p. 164. 